\title{
KARAKTERISTIK GELATIN KULIT IKAN AYAM-AYAM (Abaliste stellaris) DENGAN PRA-PERLAKUAN KONSENTRASI ASAM SITRAT
}

\author{
A. Aziz Jaziri ${ }^{\mathrm{a}, \mathrm{b}, \mathrm{c}} *$, H. Muyasyaroh ${ }^{\mathrm{a}}$, dan M. Firdaus ${ }^{\mathrm{a}, \mathrm{b}}$ \\ ${ }^{a}$ Fish Processing Technology, Faculty of Fisheries and Marine Science, University of Brawijaya \\ ${ }^{\mathrm{b}}$ Bioseafood RG at Faculty of Fisheries and Marine Science, University of Brawijaya \\ ${ }^{c}$ Halal Thoyib Science Center, University of Brawijaya \\ *Koresponden penulis : azizjaziri@ub.ac.id
}

\begin{abstract}
Abstrak
Gelatin merupakan protein berserat yang diperoleh melalui denaturasi parsial dari kolagen. Gelatin berasal dari kulit maupun tulang mamalia, seperti sapi dan babi. Namun, sumber gelatin tersebut beresiko terhadapat penyakit BSE dan FMD. Di sisi lain, bertentangan dengan aturan agama islam jika material gelatin didapatkan dari babi. Oleh karena itu, alternatif lain seperti dari limbah pengolahan ikan ayam-ayam yang berupa kulit berpotensi dieksplorasi karakteristik gelatinkarena sangat sedikit sekali penelitian yang melaporkan gelatin dari kulit ikan ayam-ayam. Tujuan dari penelitian ini adalah mendapatkan karakteristik fisikokimia gelatin dari kulit ikan ayam-ayam (GKA). Metode yang digunakan adalah eksperimen dengan menggunakan rancangan acak lengkap (RAL), dengan pra-perlakuan perendaman asam sitrat (konsentrasi: 0,2 M; 0,4 M; dan 0,6 M). Hasil penelitian ini didapatkan bahwa perbedaan pra-perlakuan pada ekstraksi gelatin dari kulit ikan ayam-ayam melalui perendaman asam sitrat dengan konsentrasi 0,2 M, 0,4 M, dan 0,6 M memberikan pengaruh nyata $(\mathrm{P}<0,05)$ pada nilai rendemen, viskositas, kekuatan gel, dan kadar lemak GKA. Sebalik, pra-perlakuan ekstraksi GKA dengan konsentrasi asam sitrat yang berbeda tidak memberikan pengaruh nyata $(\mathrm{P}>0,05)$ terhadap nilai $\mathrm{pH}$, titik leleh, titik gel, kadar air, kadari protein, dan kadar abu. Sebagian besar karakteristik GKA memenuhi standar gelatin komersial, dan dapat dijadikan alternatif potensial sebagai gelatin halal.
\end{abstract}

Kata Kunci : gelatin, kulit ikan ayam-ayam, asam sitrat

\begin{abstract}
Gelatin is a fibrous protein obtained by partial denaturation of collagen. Gelatin derived from mammals' skins and bones, such as cow and pork. However, both mammals' gelatin could risk for bovine spongiform encephalopathy (BSE) and foot mouth disease (FMD), besides, gelatin extracted from pork is prohibited in Islam rules. Therefore, fish processing waste is potential as a source of gelatin in terms of starry trigerfish (Abalistes stellaris) skin gelatin. This study aimed to characterize physicochemical of gelatin extracted from skin of starry trigerfish. The methods used in this research was experiment with completely randomized design (CDR) by soaking different concentrations of citric acid (0.2; $0.4 ;$ and $0.6 \mathrm{M})$. The results showed that the concentrations of citric acid had significantly different $(P<0.05)$ on the yield, viscosity, gel strength, and fat content of starry trigerfish skin gelatin. On the other hand, the $\mathrm{pH}$, melting point, gelling point, protein, moisture, and ash value of starry trigerfish skin gelatin did not perform significantly different $(P>0.05)$. The most porperties of starry trigerfish skin gelatin meet the commercial gelatin, and it is able to as a potential alternative of halal gelatin.
\end{abstract}

Keywords: gelatin, starry trigerfish, citric acid

\section{PENDAHULUAN}

Gelatin merupakan biopolimer protein berasal dari kolagen yang mengalami denaturasi melalui proses thermo-hidrolisis [1]. Gelatin diaplikasikan sebagai bahan tambahan atau penyusun di beberapa industri, seperti industri pangan, farmasi, kesehatan, dan fotografi. Namun, sebagain besar gelatin yang diaplikasikan pada industri pangan digunakan sebagai bahan penstabil, pembentuk gel, pengikat, pengental, pengemulsi, perekat dan pembungkus makanan. Adapun contoh produk pangan yang ditambahkan gelatin pada proses, misal 
pembuatan jeli, es krim, margarin, dan suplemen makanan. [2].

Gelatin biasatersedia dalam bentuk bubuk granular, maupun lembaran gelatin. Sebagian besar berasal dari tulang dan kulit sapi (bovine) dan babi (procine). Namun, gelatin tersebut telah memunculkan masalah baru, khususpada kesehatan dan aturan agama. Gelatin dari sapi memiliki masalah kesehatan berkaitan dengan risiko tinggi penyebaran bovine spongiform encephalopathy (BSE), dan penyakit mulut dan kaki atau dikenal sebagai penyakit sapi gila. Selain itu, umat Hindu tidak dapat mengkonsumsi produk yang berhubungan dengan sapi dan umat Islam dilarang keras mengkonsumsi produk yang berkaitan dengan babi dan turunan [3]. Oleh karena itu, alternatif lainsebagai sumber gelatin yang terjamin kehalalan dan kemanan(food safety).

Gelatin dari ikan mulai menjadi sumber alternatif gelatin dalam beberapa tahun terakhir untuk memenuhi permintaan gelatin halal. Kementerian Kelautan dan Perikanan [4] melaporkan bahwa produksi perikanan nasional mencapai 23,26 juta ton yang terdiri dari 6,04 juta ton merupakan hasil perikanan tangkap dan 17,22 ton dari hasil perikanan budidaya. Panjaitan [5] menyatakan bahwa hampir $20 \%$ hasil pengolahan ikan berupa limbah yang terdiri dari kulit, tulang, sirip, dan kepala. Jika dikalkulasikan maka limbah yang dihasilkan sebanyak 4,65 juta ton. Limbah yang dihasilkan selama proses pengolahan ikan tersebut dapat menyebabkan polusi dan pencemaran lingkungan kalau tidak dimanfaatkan. Oleh karena itu, penggunaan produk sampingan ikan untuk gelatin dapat secara signifikan mengatasi masalah lingkungan pada sejumlah besar limbah ikan dari industri pengolahan ikan.

Salah satu limbah pengolahan ikan yang potensial dikembangkan untuk produksi gelatin halal adalah kulit ikan ayam-ayam (Abalistes stellaris)atau nama lokaldisebut ikan togek. Ikan tersebut dinamakan ikan ayam-ayam karena rasa dagingseperti daging ayam. Berdasarkan dari pengamatan di lapangan, tepatdi daerah Tuban pada UKM Lapang Gange, pengolahan ikan ayam-ayam umumdijadikan ikan bakar, dimana kulitdipisahkan terlebih dahulu dari daging. Limbah kulit ikan ayam-ayam per haribisa mencapai $20-30 \mathrm{~kg}$ dan tidak ada penanganan maupun pengolahan limbah kulit ikan ayamayam. Ikan ayam-ayam memiliki ciri khas tekstur kulit yang tebal yang berbeda dari ikan jenis lain, sehingga limbah kulit ikan ayamayam berpotensi sebagai sumber gelatin halal yang sangat menjanjikan.

Gelatin dapat diekstraksi menggunakan berbagai jenis metode ekstraksi seperti ekstraksi termal, asam, basa maupun secara enzimatik. Namun, yang metode paling disukai adalah kombinasi asam dan basa karena dapat memberikan kualitas yang lebih baik dari gelatin dibandingkan dengan perlakukan termal secara langsung yang dapat menghasilkan kualitas gel yang rendah [3]. Selain itu, metode kombinasi pada perlakukan estraksi gelatin dengan pelarut asam dan basa tersebut merupakan metode terbaik ekstraksi gelatin dari kulit ikan. Sinthusamran et al.[6] dan Hashim et al. [7] melaporkan bahwa ekstraksi gelatin dengan menggunakan kombinasi asam dan basa tidak hanyadapat menghilangkan protein non-kolagen tetapi juga dapat meningkatkan kualitas fisikokimia gelatin kulit ikan kakap (Lates calcalifer), ikan cobia (Rachycentrom canadum), ikan tongkol (Euthynnus affinis) dan ikan layang (Decapterus maruadsi).

Beberapa studi di atas tidak ditemukan penelitian dan informasi mengenai pemanfaatan gelatin dari limbah kulit ikan ayam-ayam. Oleh karena itu, pada studi ini bertujuan untuk mengekstrasi gelatin dari kulit ikan ayam-ayam dengan pra-perlakuan konsentrasi asam sitrat yang berbeda untuk mendapatkan properti fisikokima gelatin dari kulit ikan ayam-ayam. Selain itu, penelitian ini juga nantidalam rangka mendukung capaian realisasi Rencana Induk Penelitian Universitas Brawijaya (RIP UB) sebagai biomaterian halal yang dapat dijadikan sebagai sumber pangan fungsional.

\section{BAHAN DAN METODE}

Bahan yang digunakan untuk pembuatan gelatin meliputi limbah ikan ayam ayam (ikan togek) yang diperoleh dari UKM Pengasapan Lapang Gange Tuban, asam sitrat, alumunium foil, kain blancu, kertas label, kertas lakmus dan aquades. Adapun bahan yang digunakan untuk analisa meliputi larutan $\mathrm{H}_{2} \mathrm{SO}_{4}$ pekat, $\mathrm{NaOH} 45 \%$, tablet Kjeldahl, $\mathrm{HCl} 0,1 \mathrm{~N}$, asam borat 3\%, larutan $\mathrm{AgNO}_{3} 0,1 \mathrm{~N}$, buffer $\mathrm{pH}$, 
kalium kromat, kertas saring Watmat nomer 1, dan aquades.

Alatyang digunakan dalam proses pembuatan gelatin yaitu baskom, blender, coolbox, stopwatch, talenan, thermometer, oven vacum, hot plate, beaker glass $250 \mathrm{ml}$ dan $1000 \mathrm{ml}$, nampan alumunium, spatula, gelas ukur $100 \mathrm{ml}$, timbangan digital, dan waterbath. Alat yang digunakan untuk analisa adalah $\mathrm{pH}$ meter, hot plate, termometer, pipet volum, beaker glass, timbangan analitik, oven vacum, cawan porselin, desikator, tanur, alat analisa protein (kjeldhal), erlenmeyer, alat titrasi, tabung reaksi, dan pipet tetes.

Metode yang digunakan adalah metode eksperimen. Metode ini bertujuan untuk mengetahui ada atau tidakpengaruh penambahan pelarut asam dan konsentrasi terhadap kualitas gelatin. Penelitian ini dilakukan dalam pembuatan gelatin dengan menggunakan larutan asam sitrat dengan konsentrasi yang berbeda.

Desain penelitian ini menggunakan rancangan acak lengkap (RAL) dengan tiga perlakuan dan 6 ulangan. Perlakuan yang dirancang terdiri dari :

1. Perlakukan 1: $0,2 \mathrm{M} \mathrm{C}_{6} \mathrm{H}_{8} \mathrm{O}_{7}$ (asam sitrat)

2. Perlakukan 1: 0,4 $\mathrm{M} \mathrm{C}_{6} \mathrm{H}_{8} \mathrm{O}_{7}$ (asam sitrat)

3. Perlakukan 1: 0,5 $\mathrm{M} \mathrm{C}_{6} \mathrm{H}_{8} \mathrm{O}_{7}$ (asam sitrat)

Adapun parameter yang digunakan dalam penelitian ini adalah fisika kimia gelatin kulit ikan ayam ayam (GKA). Parameter fisik meliputi: persentase rendemen, nilai viskositas, kekuatan gel ( $\mathrm{gel}$ strength), titik leleh (melting point), titik gel (gelling point), dan warna. Sedangkan parameter kimia terdiri dari nilai derajat keasaman $(\mathrm{pH})$, komposisi proksimat (kadar protein, kadar air, kadar lemak, dan kadar abu), dan asam amino.

\section{Prosedur penelitian}

Prosedur penelitian gelatin dari kulit ikan ayam ayam (Abalistes stellaris) meliputi proses ikan segar yang di simpan dalam es seperti yang dijelaskan oleh Soottawat [8], dengan beberapa modofikasi. Kulit direndam dalam $\mathrm{NaOH}$ dengan rasio perbandingan kulit dan larutan sebesar 1:5 (w/v). Campuran diaduk selama 2 jam pada suhu kamar. Larutan alkali diganti setiap satu jam. Kulit yang sudah basa kemudian dicuci dengan air aquades sampai $\mathrm{pH}$ netral (diukur menggunakan $\mathrm{pH}$ paper) setelah itu kulit direndam dalam larutan asam sitrat dengan rasio perbandingan sebesar 1:5 (w/v) selama 4 jam. Larutan asam diganti tiap 2 jam. Selama proses perendaman, sampel diaduk secara perlahan dan terus menerus sehingga matriks kulit membengkak. Kulit yang direndam asam kemudian dicuci menggunakan aquades sampai $\mathrm{pH}$ netral. Setelah kulit ikan mengalami pembengkakan kemudian direndam menggunakan air suling dengan rasio perbandingan sebesar 1:3 (w/v), dilakukan ekstraksi di dalam waterbath selama 4 jam dengan suhu $55{ }^{\circ} \mathrm{C}$. Kemudian campuran di saring menggunakan kain blancu. Filtrat dari hasil penyaringan di oven selama \pm 2 hari dengan suhu $55^{\circ} \mathrm{C}$. Lembaran gelatin yang kering dihaluskan menggunakan grinder untuk mendapatkan gelatin dengan fase bubuk.

\section{Analisa fisika dan kimia gelatin}

Pengamatan terhadap gelatin kulit ikan Ayam ayam bersisik meliputi analisa rendemen, $\mathrm{pH}$, analisis proksimat, logam berat, viskositas, kekuatan gel, titik leleh, titk gel, warna, analisis, analisis asam amino dan uji organoleptik

\section{Rendemen}

Rendemen gelatin dapat diperoleh dengan menghitung perbandingan antara berat tepung gelatin kering yang dihasilkan dengan berat awal (kulit ikan yang sudah dicuci bersih). Besarrendemen dapat dihitung menggunakan rumus:

$$
\text { Rendemen }(100 \%)=\frac{\text { Berat bahan kering gelatin }}{\text { Berat bahan segar }} \times 100 \%
$$

\section{Derajat keasaman (pH)}

Contoh sebanyak 0,2 gr didispersi dalam $20 \mathrm{ml}$ aquades pada suhu $80{ }^{\circ} \mathrm{C}$. Contoh dihomogenkan dengan magnetic stirer. Kemudian diukur derajat keasaman $(\mathrm{pH})$ pada suhu kamar dengan $\mathrm{pH}$ meter.

\section{Kadar air}

Penentuan kadar air dilakukan dengan metode gravimetri (pengeringan dengan oven). Metode ini memiliki prinsip bahwa air 
yang terkandung dalam bahan akan menguap apabila bahan tersebut dipanaskan dalam suhu $105{ }^{0} \mathrm{C}$ selama waktu tertentu (Jung dan Wells, 1997). Prosedur penentuan kadar air dilakukan dengan cara menimbang 5 gr contoh dan diletakkan dalam cawan kosong yang sudah ditimbang berat, cawan serta tutupsebelumsudah dikeringkan di dalam oven serta didinginkan di dalam desikator. Cawan yang berisi contoh kemudian ditutup dan dimasukkan ke dalam oven dengan suhu 100$102{ }^{\circ} \mathrm{C}$ selama 6 jam. Cawan tersebut lalu didinginkan di dalam desikator dan setelah dingin cawan ditimbang. Kadar air dapat ditimbang dengan rumus :

$$
\text { Kadar Air }=\frac{\mathrm{W}_{1}-\mathrm{W}_{2}}{\text { Berat Sampel }} \times 100 \%
$$

Keterangan :

- $\mathrm{W}_{1}=$ Berat (sampel + cawan) sebelum dikeringkan

- $\mathrm{W}_{2}=$ Berat (sampel + cawan) setelah dikeringkan

\section{Kadar $a b u$}

Prosedur penentuan kadar abu dilakukan dengan cara menimbang sebanyak 5 gr contoh dan dimasukkan ke dalam cawan pengabuan yang telah ditimbang dan dibakar di dalam tanur dengan suhu $600{ }^{\circ} \mathrm{C}$ serta didinginkan dalam desikator. Cawan yang berisi contoh dimasukkan ke dalam tanur pengabuan dan dibakar sampai didapat abu yang berwarna keabu-abuan. Pengabuan ini dilakukan dalam dua tahap, yaitu pertama pada suhu sekitar $400{ }^{\circ} \mathrm{C}$ selama 1 jam dan kedua pada suhu 550 ${ }^{\circ} \mathrm{C}$ selama 5 jam. Cawan yang berisi abu tersebut didinginkan dalam desikator dan kemudian ditimbang. Kadar abu dihitung dengan rumus :

$$
\text { Kadar Abu }=\frac{\text { Berat Abu }}{\text { Berat Sampel }} \times 100 \%
$$

\section{Kadar protein}

Penentuan kadar protein dilakukan dengan metode mikro-kjeldahl. Contoh ditimbang sebanyak 0,2 gr dan dimasukkan ke dalam labu kjeldahl $30 \mathrm{ml}$. Kemudian ditambah $2 \mathrm{gr} \mathrm{K}_{2} \mathrm{SO}_{4}, 50 \mathrm{mg} \mathrm{HgO}$ dan 2,5 ml $\mathrm{H}_{2} \mathrm{SO}_{4}$. Contoh didestruksi selama 1-1,5 jam sampai cairan berwarna hijau jernih lalu didinginkan dan ditambah air suling perlahanlahan. Isi labu dipindahkan ke dalam alat destilasi, ditambah $10 \mathrm{ml} \mathrm{NaOH}$ pekat sampai berwarna coklat kehitaman lalu didestilasi. Hasil destilasi ditampung dalam erlenmeyer $125 \mathrm{ml}$ yang berisi $5 \mathrm{ml} \mathrm{H}_{3} \mathrm{BO}_{3}$ dan dititrasi dengan $\mathrm{HCl} 0.02 \mathrm{~N}$ sampai terjadi perubahan warna menjadi merah muda. Perhitungan kadar protein menggunakan rumus :

$$
\% \mathrm{~N}=\frac{(\mathrm{ml} \mathrm{HCl}-\mathrm{ml} \text { blanko }) \times 14.007 \times \mathrm{N} \mathrm{HCl}}{\mathrm{mg} \mathrm{Sampel}} \times 100 \%
$$

$\%$ Protein $=\% \mathrm{~N} \times 6,25$

\section{Kadar lemak}

Kadar lemak dapat ditentukan menggunakan metode soxhlet. Contoh sebanyak 2 gr ditimbang dan dibungkus dengan kertas saring lalu ditutup dengan kapas bebas lemak dan dimasukkan ke dalam labu lemak. Setelah itu diletakkan ke dalam alat ekstraksi soxhlet, dengan posisi alat kondensor berada di atas dan labu lemak di bawah. Petroleum benzene ditambahkan ke dalam labu lemak kemudian dilakukan ekstraksi selama \pm 6 jam pada suhu $40{ }^{\circ} \mathrm{C}$ hingga pelarut yang turun kembali ke labu lemak menjadi jernih. Pelarut yang ada di dalam labu lemak didestilasi sehingga semua pelarut lemak menguap. Selanjutlabu lemak hasil ekstraksi dikeringkan dalam oven pada suhu $105{ }^{\circ} \mathrm{C}$. Setelah itu labu didinginkan dalam desikator dan ditimbang. Penentuan kadar lemak menggunakan rumus:

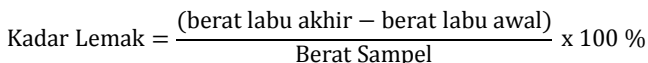

\section{Kekuatan gel}

Larutan gelatin konsentrasi 6,67\% disiapkan dengan aquades, kemudian diaduk sampai homogen, suhu $60^{\circ} \mathrm{C}$ selama 15 menit menggunakan hot plate magnetic stirrer. Tuang larutan dalam beaker glass $100 \mathrm{ml}$, tutup dan diamkan selama 2 menit. Inkubasikan pada suhu $10^{\circ} \mathrm{C}$ selama $17 \pm 2$ jam. Selanjutdiukur menggunakan alat digital force gauge. 


\section{Viskositas}

Viskositas gelatin diukur dengan menggunakan asat Brookfield Syncro-Lectric Viscometer. Sebelum diukur, sampel gelatin dengan konsentrasi $6,67 \%$ (b/b) disiapkan dengan aquades ( 7 gr gelatin ditambah $105 \mathrm{ml}$ aquades) kemudian larutan diukur viskositas. Proses pengukuran dilakukan pada suhu $60{ }^{\circ} \mathrm{C}$ dengan laju geser $60 \mathrm{rpm}$ menggunakan spindel. Hasil pengukuran dikalikan dengan faktor konversi.

\section{Titik leleh}

Larutan gelatin dengan konsentrasi $6,67 \%$ (b/b) disiapkan dengan aquades. Contoh diinkubasi pada suhu $10{ }^{\circ} \mathrm{C}$ selama 17 \pm 2 jam. Pengukuran titik leleh dilakukan dengan cara memanaskan gel gelatin dalam waterbath. Diatas gel gelatin tersebut diletakkan gotri dan ketika gotri jatuh ke dasar gel gelatin maka suhu tersebut merupakan suhu titik leleh.

\section{Titik gel}

Larutan gelatin dengan konsentrasi $6,67 \%(\mathrm{~b} / \mathrm{b})$ disiapkan dengan aquades dan disimpan dalam tabung reaksi yang dihubungkan dengan termometer digital kemudian diberikan es pada keliling luar bagian tabung reaksi. Titik gel adalah suhu ketika larutan gelatin mulai menjadi gel.

\section{Analisa statistik}

Semua percobaan dilakukan dalam 6 kali ulangan dengan 3 perlakukan yang berbeda. Data dianalisis keragaman (ANOVA) dan perbandingan rata-rata dilakukan menggunakan uji rentang berganda Duncan.

\section{HASIL DAN PEMBAHASAN}

\section{Rendemen}

Rendemen merupakan salah satu parameter yang penting dalam proses pembuatan gelatin. Semakin besar jumlah rendemen yang dihasilkan maka semakin efisien perlakuan yang diterapkan dengan catatan tidak mengesampingkan sifat fisika maupun kimia yang lain. Rendemen merupakan hasil perbandingan berat kering gelatin yang dihasilkan dengan berat kulit ikan yang digunakan sebagai bahan baku [9]. Nilai rendemen gelatin dari kulit ikan ayam-ayam yang diekstrak dengan asam sitrat melalui perlakuan konsentrasi yang berbeda $(0,2 ; 0,4$; dan $0,6 \mathrm{M}$ ) dapat dilihat pada Gambar 1 .

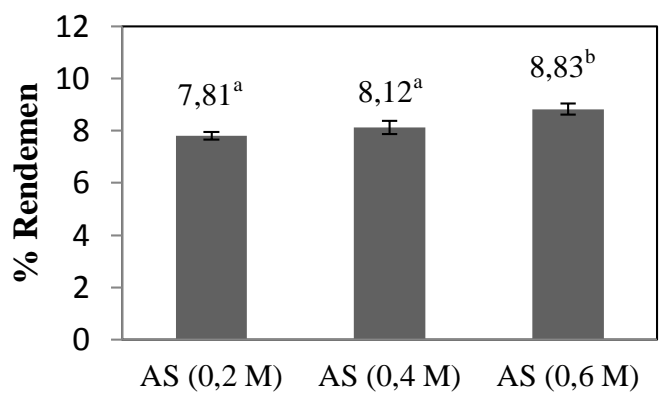

Gambar 1. Nilai rendemen GKA (\%)

Berdasarkan hasil analisis varians (ANOVA) diketahui bahwa praperlakukan dengan konsentrasi asam sitrat $(0,2 \mathrm{M} ; 0,4 \mathrm{M}$; dan 0,6 M) memberikan pengaruh nyata $(\mathrm{P}<0,05)$ terhadap persentase rendemen GKA. Kemudian, hasil uji dilanjutkan dengan metode Duncan untuk mendapatkan perlakukan terbaik dari GKA. Hasil uji lanjut menunjukkan bahwa perendaman asam sitrat dengan konsentrasi 0,6 M didapatkan nilai terbaik rendemen sebesar $8,83 \%$. Hasil penelitian menunjukkan bahwa semakin tinggi konsentrasi larutan asam yang diberikan maka persentase rendemen yang dihasilkan semakin banyak. Hal ini dikarenakan senyawa asam berfungsi untuk menghidrolisis kolagen pada kulit ikan sehingga struktur gelatin yang dihasilkan lebih mudah terurai pada saat proses ekstraksi [10].

Beberapa peneliti melaporkan bahwa gelatin dari kulit ikan mempunyai persentase rendemen yang berbeda-beda, seperti $6,12 \%$ rendemen gelatin dari kulit ikan pogot (Aluterus monoceros) dengan perlakuan asam asetat $(0,2 \mathrm{M})$ [11]. Selain itu, Jamilah dan Harvinder [12] juga melaporkan bahwa gelatin dari kulit ikan nila merah dan hitam sebesar 7,81\% dan 5,39\%. Berdasarkan beberapa penelitian tersebut menunjukkan bahwa rendemen gelatin dari kulit ikan ayam ayam lebih tinggi. 


\section{Nilai pH}

$\mathrm{pH}$ gelatin merupakan derajat keasaman yang menjadi salah satu parameter penting dalam standart mutu gelatin. Pengukuran nilai $\mathrm{pH}$ larutan dilakukan untuk mengetahui sifat gelatin yang berkaitan dengan parameter uji gelatin lain, seperti viskositas dan kekuatan gel. Nilai rerata $\mathrm{pH}$ gelatin kulit ikan ayam ayam dapat dilihat pada Gambar2.

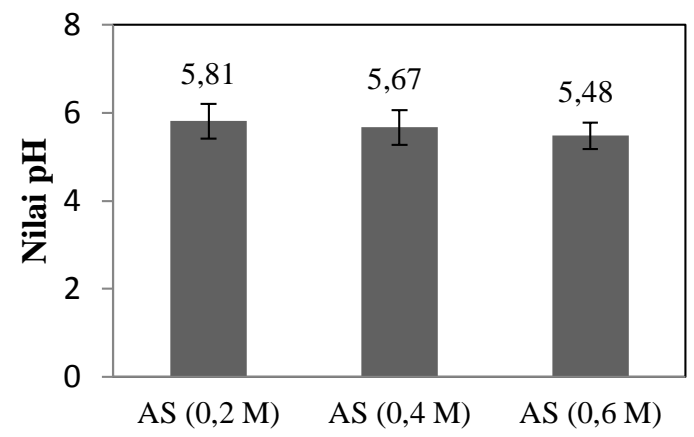

Gambar 2. Nilai pH GKA

Berdasarkan hasil analisis varians menunjukkan bahwa perbedaan konsentasi asam sitrat tidak berpengaruh nyata $(\mathrm{P}>0,05)$ terhadapat nilai $\mathrm{pH}$ GKA. Hal ini berarti bahwa perbedaan semua perlakukan tidak memberikan pengaruh signifikan terhadap nilai $\mathrm{pH}$ dari GKA. Nilai $\mathrm{pH}$ GKA berkisar 5,48-5,81. Nilai ini masih memenuhi standar gelatin tipe A disyaratkan Tourtellote [13] yanitu berkisar antara 3,8-6,0. Hasil penelitian menunjukkan semakin tinggi konsentrasi asam sitrat yang digunakan pada proses perendaman mempengaruhi nilai $\mathrm{pH}$ gelatin. Selain itu, proses pencucian yang kurang bersih menyebabkan residu asam tertinggal dalam jaringan kolagen sehingga pada saat proses ekstraksi residu asam ikut terlarut sehingga gelatin yang dihasilkan bersifat asam.

\section{Viskositas GKA}

Viskositasadalah salah satu sifat fisik gelatin yang cukup penting. Pengujian viskositas bertujuan untuk mengetahui tingkat kekentalan gelatin sebagai lerutan pada konsentrasi dan suhu tertentu. Nilai viskositas gelatin kulit ikan ayam ayam dapat dilihat pada Gambar 3.

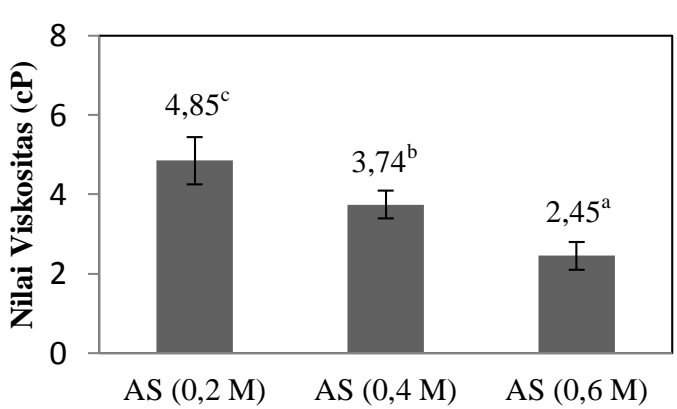

Gambar 3. Nilai viskositas GKA (cP)

Hasil analisis varians menunjukkan bahwa pra-perlakuan konsentrasi asam sitrat (0,2 M; 0,4 M; dan 0,6 M) memberikan pengaruh signifikan $(\mathrm{P}<0,05)$ terhadap nilai viskositas GKA. Dari hasil tersebut, dilanjutkan uji Duncan untuk mendapatkan perlakukan terbaik dari nilai viskositas GKA. Berdasarkan hasil uji lanjut diketahui bahwa perlakukan terbaik dengan konsentrasi asam sitrat $0,2 \mathrm{M}$ sebesar 4,85 $\mathrm{cP}$. Nilai viskositas tersebut telah memenuhi persyaratan yang dikemukakan Tourtellote [13] yaitu 2,0-7,5 cP. Selain itu Boran et al. [14] melaporkan bahwa gelatin dari kulit ikan mempunyai nilai viskositas yang berkisar $2.2-7.0 \mathrm{cP}$. Gelatin dengan nilai viskositas rendah mengasilkan gel yang rendah, sebalikgelatin dengan viskositas tinggi mengasilkan gel yang kuat [1].

\section{Kekuatan gel}

Kekuatan gel merupakan sifat fisik dari gelatin yang utama. Hal ini dikarenakan kekuatan gel menunjukkan kemampuan gelatin dalam proses pembentukan gel. Nilai kekuatan gel GKA dapat dilihat pada Gambar 4.

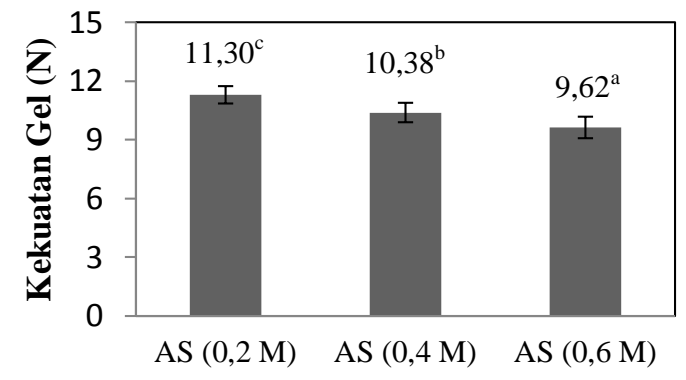

Gambar 4. Nilai kekuatan gel GKA (N) 
Dari hasil analisis varians menunjukkan bahwa perbedaan konsentrasi asam sitrat $(0,2$ M; 0,4 M; dan 0,6 M) memberikan pengaruh signifikan $(\mathrm{P}<0,05)$ terhadap nilai kekuatan gel GKA. Selanjt, dilakukan analisis uji lanjut dengan metode Duncan untuk mendapatkan perlakukan terbaik dari nilai kekuatan gel GKA. Hasil uji lanjut diketahui bahwa konsentrasi terbaik didapatkan pada konsentrasi asam 0,2 M sebesar 11,30 N. Hal ini berarti bahwa semakin tinggi konsentrasi asam sitrat yang digunakan pada praperlakukan, maka semakin rendah nilai kekuatan gel gelatin kulit ikan ayam ayam. Yenti et al. [15] melaporkan bahwa kekuatan gel gelatin berkisar 0,67-1,46 N.Gelatin sapi memiliki kekuatan gel sebesar 3,22 N, sedangkan kekuatan gel gelatin ikan sebesar $1,81 \mathrm{~N}[16]$.

\section{Titik leleh}

Titik leleh merupakan suhu dimana gelatin yang berbentuk gel mencair saat dipanaskan perlahan-lahan. Nilai rerata titik lele gelatin kulit ikan ayam ayam dapat dilihat pada Gambar 5.

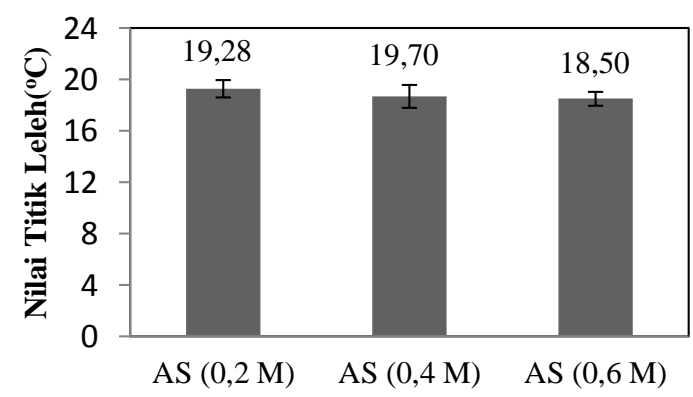

Gambar 5. Nilai titik lele GKA $\left({ }^{\circ} \mathrm{C}\right)$

Hasil analisis keragaman menunjukkan bahwa perbedaan konsentrasi asam sitrat $(0,2$ $\mathrm{M}$; 0,4 M; dan 0,6 M) tidak pengaruh nyata $(\mathrm{P}>0,05)$ terhadap nilai titik leleh (melting point) GKA. Arti, ketiga pra-perlakuan tersebut tidak memberikan pengaruh terhadap nilai titik leleh GKA. Adapun nilai titik leleh GKA berkisar 18,50 - 19,28 ${ }^{\circ} \mathrm{C}$. Berdasarkan Food Chemical Codex, produk gelatin adalah produk yang mengalami pelelehan pada suhu $<35^{\circ} \mathrm{C}$ dan dapat mencair dalam mulut. Beberapa peneliti melaporkan bahwa gelatin dari kulit ikan memiliki nilai titik leleh bervariasi, seperti $22,61{ }^{\circ} \mathrm{C}$ pada ikan pogot, $8-10{ }^{\circ} \mathrm{C}$ pada ikan kod, $14{ }^{\circ} \mathrm{C}$ pada ikan hake,
$19,4{ }^{\circ} \mathrm{C}$ pada ikan sebelah (sole), $18,8^{\circ} \mathrm{C}$ pada ikan pipih (megrim), dan $19,5^{\circ} \mathrm{C}$ ikan mas [17].

\section{Titik gel}

Titik gel merupakan suhu dimana larutan gelatin mulai berubah menjadi gel. Proses pembentukan gel dipengaruhi oleh konsentrasi gelatin dalam larutan, $\mathrm{pH}$, dan besarmolekul gelatin. Nilai rerata titik gel GKA dapat dilihat pada Gambar 6.

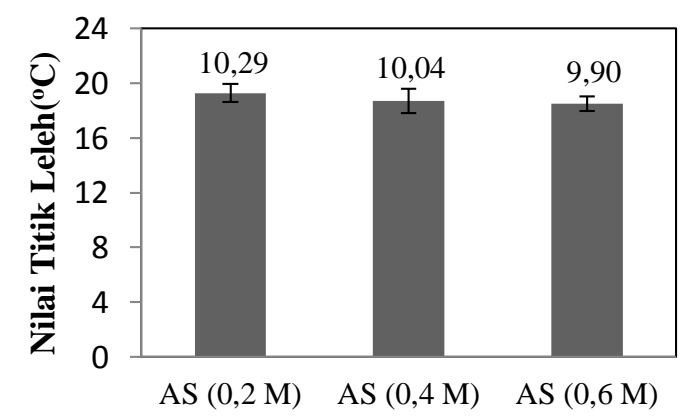

Gambar 6. Nilai titik gel GKA $\left({ }^{\circ} \mathrm{C}\right)$

Hasil analisis varians menunjukkan bahwa perbedaan konsentrasi asam sitrat tidak berpengaruh nyata $(\mathrm{P}>0,05)$ terhadap nilai titik gel GKA. Hal ini berarti bahwa perbedaan perlakukan konsentrasi asam sitrat tidak memberikan pengaruh signifikan terhadap nilai titik gel dari GKA. Nilai titik gel GKA berkisar 9,90- $10,29{ }^{\circ} \mathrm{C}$. Beberapa peneliti melaporkan bahwa titik gel gelatin kulit ikan kod dan ikan salmon sebesar $10{ }^{\circ} \mathrm{C}$ dan $12{ }^{\circ} \mathrm{C}$ [18] Hasil penelitian diketahui bahwa gelatin dari kulit ikan ayam ayam memiliki titik gel lebih rendah dari gelatin komersil yaitu sebesar $19,50{ }^{\circ} \mathrm{C}$. Titik gel gelatin dipengaruhi kadar protein dalam hal ini amino prolin dan hydroksiprolin [19].

\section{Analisis proksimat GKA}

\section{Kadar protein}

Protein merupakan komponen utama gelatin yang dihasilkan melalui proses hidrolisis kolagen. Gelatin merupakan protein murni yang diperoleh dari penguraian kolagen dengan menggunakan suhu $<70^{\circ} \mathrm{C}$. Nilai kadar protein GKA dapat dilihat diGambar 7. 


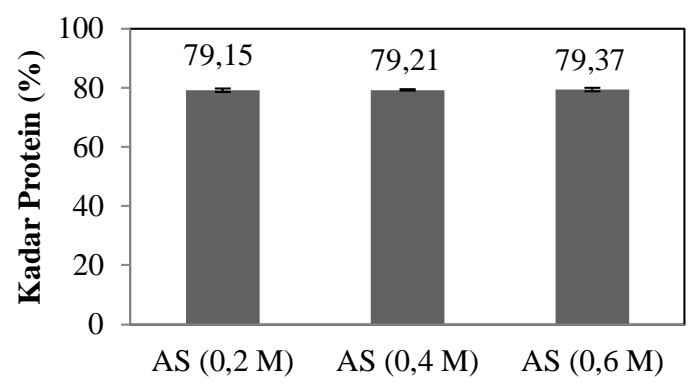

Gambar 7. Kadar protein GKA

Hasil analisis sidik ragam menunjukkan bahwa perbedaan konsentrasi asam sitrat yang diberikan tidak berpengaruh nyata $(P>0,05)$ terhadap nilai kadar protein GKA. Kadar protein GKAberkisar 79,15-79,37\%. Nilai ini menunjukkan gelatin hasil penelitian ini di bawah SNI adalah 85-90\%. Hasil penelitian memungkinkan bahwa perendaman asam sitrat dengan konsentrasi 2,0-0,6 M yang digunakan masih belum menghilangkan komponen non-kolagen pada proses ekstraksi. Kadar protein bahan yang digunakan memiliki peranan penting terhadap tinggi rendahrendemen yang dihasilkan serta kualitas akhir dari sifat fisik dan kimia yang diinginkan. Komposisi dan kondisi raw material sangat berpengaruh terhadap hasil akhir dari pembuatan gelatin. Semakin bagus kualitas bahan baku yang digunakan maka semakin maksimal kadar protein yang dihasilkan [20].

\section{Kadar air}

Kadar air merupakan banyakair yang terkandung didalam bahan yang dinyatakan dalam satuan persen. Kadar air merupakan salah satu karakteristik yang sangat penting pada bahan pangan, karena air dapat mempengaruhi penampakan, tekstur, dan citarasa bahan pangan. Nilai kadar air dari gelatin kulit ikan ayam ayam dapat dilihat pada Gambar 8.

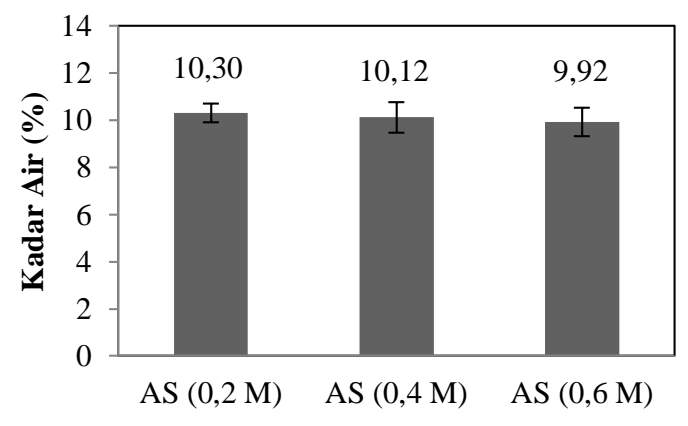

Gambar 8. Kadar air GKA

Hasil analisis sidik ragam menunjukkan bahwa perbedaan konsentasi asam tidak berpengaruh nyata $(\mathrm{P}>0,05)$ terhadapat nilai kadar air GKA. Nilai kadar air GKA yang diperoleh berkisar 9,92-10,30 \%. Kadar air gelatin yang hasilkan dari penelitian ini masih sesuai standart SNI 1995, dimana batas maksimal kadar air yang diperbolehkan sebesar $16 \%$.

Penurunan kadar air disebabkan oleh struktur kolagen yang semakin terbuka. Proses tersebut menyebabkab gelatin yang dihasilkan memiliki struktur yang lemah juga, sehingga daya ikan air pada gelatin kurang kuat. Hal itu menyebabkan air mudah menguap saat proses pengeringan gelatin pada suhu $55^{\circ} \mathrm{C}$, sehingga kadar air gelatin kering lebih rendah [21].

\section{Kadar lemak}

Kadar lemak merupakan komponen yang berpengaruh terhadap perubahan mutu produk pangan selama proses penyimpanan. Kerusakan lemak yang paling utama diakibatkan oleh proses oksidasi. Gelatin dengan kualitas mutu tinggi memiliki kandungan lemak yang rendah. Kadar lemak tidak perbolehkan melebihi batas 5\%. Nilai rerata kadar lemak GKA dapat dilihat pada Gambar 9.

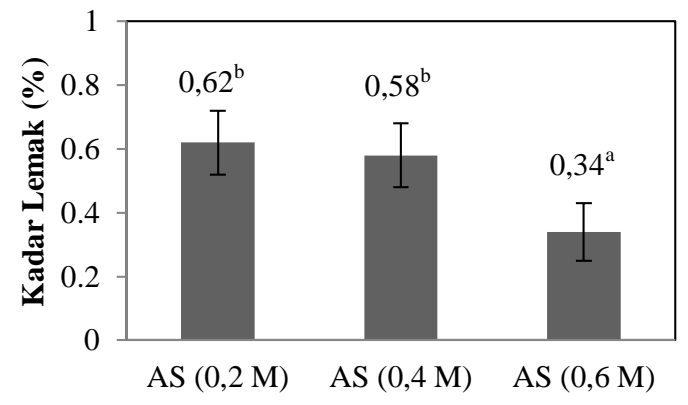

Gambar 9. Kadar lemak GKA 
Hasil analisis varians menunjukkan bahwa perbedaan konsentrasi asam sitrat $(0,2$ M; 0,4 M; dan 0,6 M) memberikan pengaruh nyata $(\mathrm{P}<0,05)$ terhadap persentase kadar lemak GKA. Kemudian, hasil uji dilanjutkan dengan metode Duncan untuk mendapatkan perlakukan terbaik dari persentase kadar lemak GKA. Berdasarkan hasil uji lanjut menunjukkan bahwa perlakuan terbaik untuk mengahasilkan GKA dengan rerata kadar lemak sebesar 0,34\%. Hasil penelitian menunjukkan bahwa semakin tinggi konsentrasi larutan asam yang diberikan maka persentase lemak yang dihasilkan semakin rendah. Kadar lemak sangat bergantung pada perlakuan selama proses pembuatan, baik pada tahap pembersihan kulit maupun degreasing sampai pada tahap penyaringan filtrat hasil ekstraksi. Perlakuan yang baik dari setiap proses akan mengurangi kandungan lemak yang terdapat dalam bahan baku sehingga produk yang dihasilkan memiliki kadar lemak yang rendah. Selain itu, tinggi rendahkadar lemak pada gelatin juga dipengaruhi oleh faktor bahan baku yang digunakan untuk membuat gelatin [22].

\section{Kadar $a b u$}

Kadar abu merupakan parameter yang digunakan untuk menentukan banyakmineral yang terikat dalam suatu bahan. Abu adalah sat anorganik yang tidak ikut terbakar dalam proses pembakaran zat organik. Nilai rerata kadar abu gelatin kulit ikan ayam ayam dapat dilihat pada Gambar10.

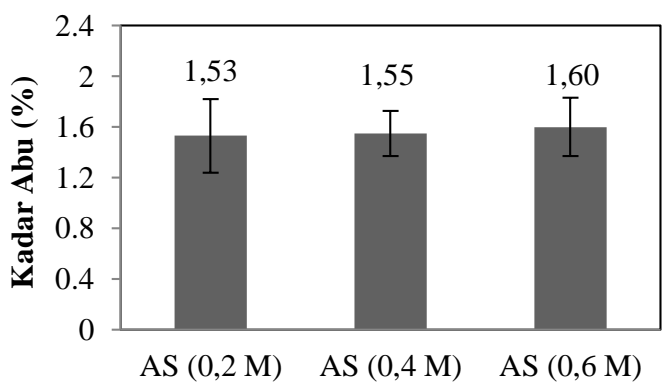

Gambar 10. Kadar abu GKA

Berdasarkan hasil analisis sidik ragam menunjukkan bahwa perbedaan konsentrasi asam sitrat tidak berpengaruh nyata $(\mathrm{P}>0,05)$ terhadapat nilai kadar abu GKA. Nilai rerata kadar abu GKA yang diperoleh berkisar 1,53-
1,60 \%. Berdasarkan nilai kadar abu standar FAO dan SNI 1995, maka nilai kadar abu gelatin ikan ayam ayam memenuhi standar tersebut, dimana pada standar FAO menyatakan bahwa kadar abu produk gelatin maksimal $2 \%$ dan pada standar SNI maksimal 3,2\%.

\section{KESIMPULAN}

Penelitian tentang pengaruh konsentrasi pra-perlakuan asam sitrat terhadap karakteristik fisikokimia gelatin kulit ikan ayam-ayam ini dapat disimpulkan bahwa Perbedaan pra-perlakuan pada ekstraksi gelatin dari kulit ikan ayam-ayam melalui perendaman asam sitrat dengan konsentrasi 0,2 M, 0,4 M, dan 0,6 M memberikan pengaruh nyata $(\mathrm{P}<0,05)$ pada nilai rendemen, viskositas, kekuatan gel, dan kadar lemak GKA. Sebalik, pra-perlakuan ekstraksi GKA dengan konsentrasi asam sitrat yang berbeda tidak memberikan pengaruh nyata $(\mathrm{P}>0,05)$ terhadap nilai $\mathrm{pH}$, titik leleh, titik gel, kadar air, kadari protein, dan kadar abu. Sebagian besar karakteristik GKA memenuhi standar gelatin komersial, dan dapat dijadikan alternatif potensial sebagai gelatin halal.

\section{UCAPAN TERIMAKASIH}

Penulis menyampaikan terimakasih kepada Universitas Brawijaya, dalam hal ini Lembaga Penelitian dan Pengabdian Masyarakat (LPPM) Universitas Brawijaya, atas Hibah Penelitian Pemula (HPP) . Ucapan terimakasih disampaikan juga kepada Tim Peneliti yang telah membantu dalam menjalankan penelitian.

\section{DAFTAR PUSTAKA}

[1] Silva, R. S. G., Bandeira, S. F., and Pinto, L. A. A Characteristics and Chemical Composition of Skins Gelatin from Cobia (Rachycentron canadum). LWT-Food Science and Technology. (57): 580-585. 2014.

[2] Gómez-Guillén, M. C., Giménez, B., López-Caballero, M. E., and Montero, M. P. Functional and bioactive properties of collagen and gelatin 
from alternative sources: a review. Food Hydrocolloids, (25): 1813-1827. 2011.

[3] Herpandi, N., Huda, N., and Adzitey, F. Fish bone and scale as potential sources of halal gelatin. Journal of Fisheries and Aquatic Science 6 (4): 379-389. 2011.

[4] Kementerian Kelautan dan Perikanan. Data Produksi Perikanan Nasional. KKP, Jakarta. 2017.

[5] Panjaitan, T. F. C. Optimasi Ekstraksi Gelatin dari Tulang Ikan Tuna (Thunnus albacares). Jurnal Wiyata, Vol 3 (1): 11-16. 2016.

[6] Sinthusamran, S., Benjakul, S., and Kishimura, H. Characteristics and Gel Properties of Gelatin from Skin of Seabass (Lates calcarifer) as Influenced by Extraction Conditions. Food Chemistry (152): 276-264. 2014.

[7] Hashim, E. F., Yan, H. J., and Ghani, I. F. Preliminary Characterization on Physical Properties of Selected Marine Fish Skins as Alternative Sources of Halal Gelatin. Food Science and Nutrition Technology. Vol 2 (2): 000117. 2017.

[8] Benjakul, S., Oungbho, K., Visessanguan, W., Thiansilakul, Y., and Roytrakul, S. Characteristics of gelatin from the skins of big eyes napper, Priacanthus tayenus and Priacanthus macracanthus. Food Chemistry, 116 (2), 445-451. 2009

[9] Yuniarifin, H., Bintoro, V. P. dan Suwarastuti, A.Pengaruh Berbagai Konsentrasi Asam Fosfat pada Proses Perendaman Tulang Sapi terhadap Rendemen, Kadar Abu dan Viskositas Gelatin. Jurnal of Indonesian Tropical Animal Agriculture. 31 (1): 55-61. 2006.

[10] Lombu, Farah V., Agnes T.A dan Engel V.P. Pemberian Konsentrasi Asam Asetat pada Mutu Gelatin Kulit Ikan Tuna. Jurnal Media Teknologi Hasil Perikanan. 3 (2): 25-28. 2015.
[11] Ahmad, M., and Benjakul, S. Characteristics of gelatin from the skin of unicorn leather jacket (Aluterus monoceros) as influenced by acid pretreatment and extraction time. Food Hydrocolloids, 25 (3): 381-388. 2011.

[12] Jamilah, B., Tan, K. W., Umi Hartina, M. R., and Azizah, A. Gelatins from three culture freshwater fish skins obtained by liming process. Food Hydrocolloids, (25): 1256-1260. 2011.

[13] Tourtellote, P. Gelatin. In: Encyclopedia of Science and Technology. , New York : McGrawHill Book Company. 1980.

[14] Boran, G., Lawless, H. T., and Regenstein, J. M. Effect of extraction conditions on the sensory and instrumental characteristics of fish gelatin gels. Journal of Food Science, (75): S469-S476. 2010.

[15] Yenti, Revi., D. Noviandi dan R. Fithriyah. Pengaruh Beberapa Jenis Larutan Asam pada Pembuatan Gelatin dari Kulit Ikan Sepat Rawa (Trichogaster trichopterus) Kering sebagai Gelatin Alternatif. SCIENTIA. 5 (2): 114-121. 2015.

[16] Wahyuni, M dan R. Peranginangin. Perbaikan Daya Saing Industri Pengolahan Perikanan Melalui Pemanfaatan Limbah Non Ekonomis Ikan Menjadi Gelatin. 2007.

[17] Gimenez, B., Gormez-Guillen, M.C. and Montero, P. The role of salt washing of fish skins in chemical and rheological properties of gelatin extracted. Journal of Food Hydrocolloids, (19): 951-957. 2005.

[18] Arnesen, J. A., dan Gildberg, A. Extraction and characterization of gelatin from Atlantic salmon (Salmo salar) skin.Bioresource Technology, (98):53-57. 2007 
[19] Nurilmala, M. Kajian Potensi Limbah Tulang Ikan Keras (Teleostei) sebagai Sumber Gelatin dan Analisis Karakterisasi. Tesis. IPB, Bogor. 2004.

[20] Ockerman, H. W., dan C. L. Hansen. Animal by Product Processing Utilization. CRC Press. USA. 2000.

[21] Astawan, M. dan Aviana T. Pengaruh Jenis Larutan Perendaman serta Metode Pengeringan terhadap Sifat Fisik, Kimia, dan Fungsional dari Kulit Ikan Cucut. Jurnal Teknologi dan Industri Pangan. (14): 7-13. 2003.

[22] Yenti, Revi., D. Noviandi dan R. Fithriyah. Pengaruh Variasi Konsentrasi Asam Asetat Terhadap Kuantitas Gelatin dari Kulit Ikan Sepat Rawa (Trichogaster trichopterus) Kering dan Karakterisasi. SCIENTIA. 6 (1): 3643. 2016. 